UDK 656.612

DOI https://doi.org/10.32838/2663-5941/2019.4-2/22

Lapkina I.O.

Odessa National Maritime University

Malaksiano M.O.

Odessa National Maritime University

Glavatskykh V.I.

Odessa National Maritime University

\title{
TO THE ISSUE OF THE POSSIBILITY OF OPERATING VESSELS AT SLOW SPEEDS
}

The instability of the freight market caused a high level of competition between shipping companies. In order to improve their competitiveness on the market, ship owners and operators have to optimize their costs, including fuel consumption costs. Since fuel consumption is directly dependent on the speed of the vessel, the operation of vessels at slow speeds is widely used in world practice. Therefore, studies aimed at substantiating an economically reasonable speed of vessels are particularly relevant.

The ways of increasing the efficiency of the operational phase of fleet replenishment projects have been investigated, taking into account the possibility of operating vessels at slow speeds. To do this, the analysis of the dependence of fuel consumption on the vessel speed is carried out. The vessel operation at slow speeds helps to achieve a significant reduction in fuel consumption and, consequently, effectively serves for operating costs reduction. The analysis of the efficiency of long-term investments, which include the acquisition of vessels, is quite complicated. It is associated with long time intervals and requires a comprehensive assessment of future conditions. The Net Present Values (NPV) of the projects for the acquisition and operation of vessels were calculated. Changes in the NPV values for the acquisition and operation options of the vessels depending on the speed were studied. It was shown that the efficiency of the acquisition and operation options of bulk carriers can be significantly improved through a reasonable choice of the vessel speed.

The calculations showed that at different speed regimes the best values of performance indicators can be achieved by different vessels. Therefore, the optimal choice of vessels should be made, taking into account the speed regime they are planned to operate. The completed study allows us to make a substantiated choice of the purchase option and the subsequent vessel operation.

Key words: dry bulk shipping, fuel consumption, optimal speed, sea transport, slow speed.

Formulation of the problem in general. The instability of demand for shipping and plenty of vessels caused a high level of competition between shipping companies. In order to improve their competitiveness on the chartering market, ship owners and operators have to optimize costs, including fuel costs. Since fuel consumption is directly dependent on the speed of the vessel, the operation of vessels at slow speeds is widely used in world practice. Therefore, studies aimed at choosing an economically reasonable speed of vessels are particularly relevant.

When determining the main directions of a shipping company's investment policy, it is worth to note that international shipping is a fairly specific form of activity exposed to the influence of a multitude of factors. Although shipping is a dynamically changing business with many restrictions and options, the ship owners' objectives remain unchanged: they strive to operate their fleet so as to achieve the most efficient utilization of the available tonnage.

The available tonnage changes as a result of natural aging, and requires efficient timely renewal. Financing a project of ship acquisition is a fairly risky undertaking that requires essential substantiation. Under such conditions it is important to carry out a careful analysis of alternative investments. These include purchase of new tonnage (newly built ships), purchase of tonnage previously operated by other shipping companies (second-hand tonnage), or upgrading of existing ships.

Analysis of recent publications on the subject of research. There are a number of studies on the wide range of problems concerning management of shipping companies and their optimal investment policy. Some basic methods of management of shipping companies and their optimal investment policy are discussed in [1-3]. 
One of the critical problems of the shipping business is associated with the market entry-exit decisions and the investment timing for asset allocation. In [4] shipping assets and market entry decisions are studied from the point of business cycles in the dry cargo shipping. The problem of market entry decision is addressed according to the maximum return on equity condition. In order to solve the problem, a number of indicators are discussed under the business cycle perspective and the fluctuation of the return on equity is estimated in the long-run framework.

The study, proposed in [5] deals with the problem of cargo type selection for the dry bulk ship companies by means of fuzzy multicriteria decision-making approach. The evaluation process is based on identifying criteria sets and ranking them according to factor loads using fuzzy AHP. The criteria include net profit from freight, cargo handling conditions, total fuel consumption and others.

In the paper [6] fuel consumption levels of liner vessels at various speeds are estimated. Through an extensive analysis of liner service characteristics, fuel costs and fuel surcharges authors explore the impact of slow steaming on fuel consumption and liner service characteristics, and evaluate the extent to which slow steaming has changed the relation between fuel costs and fuel surcharges imposed on shippers by shipping lines. Relations between slow steaming practices and fuel surcharge policies of shipping lines are explored.

There are several ways to reduce the cost of combustibles and lubricants. One of the ways is to update the fleet with new-generation vessels, which are equipped with modern economical engines. This course is associated with attracting significant investment. The issues of substantiation of the strategies for operating and replacing equipment, taking into account uncertainties, are studied in $[7 ; 8]$. The work of [9] is devoted to the issues of economic substantiation in the design of sea cargo ships. In papers [10; 11], the issues of replacing equipment are considered with regard to the growth of wear and tear. The substantiation of the optimal service life of the equipment, taking into account both wear and tear and obsolescence, was studied in article [12].

Another way to reduce fuel consumption in the vessel operation is to select and ensure optimal operating conditions of the ship's power plant, as well as various organizational and technical measures to save combustibles and lubricants. Reducing the speed during the vessel operation can significantly reduce the vessel operating costs and is widely used in practice.

Fluctuations of fuel prices and strict regulations of emissions are the leading factors which influence the maritime shipping industry and made shipping companies and ship owners find ways to reduce and optimize fuel consumption. Some different measures and approaches aimed at the reduction of fuel consumption are discussed in [13]. Among these approaches were those based on the optimizing the ship construction (such as construction of hull, propeller, etc.), and those related to routes optimization and speed control.

Paper [14] is devoted to exploration of the process of setting warranted ship speed and fuel consumption in ocean shipping time charter contracts. A conceptual model was proposed in which warranted ship speed and fuel consumption are related to an underperformance claim. Thus, in [14] authors study warranted and fuel consumption from various contract terms, ship characteristics, and market variables based on an empirical model for warranted ship speed and fuel consumption and time charter fixture data.

Great attention of the leading shipping and carrier companies is focused on the development of measures to reduce fuel costs. These include measures for organizing transportation (combining routes, reducing operating speed, providing favorable navigation conditions), measures for technological improvement (improvement of the hull design, new technologies for ship engines, use of alternative energy sources, computer technologies).

Saving combustibles and lubricants on ships is an important complex task that requires an effective solution not only because it provides an increase in profits, but also due to the fact that the rational use of energy resources can significantly reduce the amount of combustion products emitted into the atmosphere. At the same time, reducing fuel consumption, as a rule, saves the service life of the main engines of a vessel and generating units of ship power plants. This reduces the thermal stress of parts and assemblies of ship machinery and mechanisms and consumption of lubricants.

In [2], the optimal speed of vessels in tramp navigation is investigated. The methods of substantiation of the optimal speed when designing ships were studied in [9]. Studies [15-19] and a number of other studies are devoted to the study of the dependence of fuel consumption on the speed and the development of methods for choosing the optimal operational speed of ships.

The purpose of the work is to develop measures aimed at improving the operational efficiency of vessels used in tramp navigation, as well as the rationale for the methods of substantiation of the choice of a vessel acquisition option, taking into account the possibility of its operation at various speeds. 
Table 1

The main characteristics of the expectant vessels

\begin{tabular}{|c|c|c|c|c|}
\hline & Vessel 1 & Vessel 2 & Vessel 3 & Vessel 4 \\
\hline Type of the vessel & bulk carrier & bulk carrier & bulk carrier & bulk carrier \\
\hline Year built & 2014 & 2004 & 1997 & 2018 \\
\hline Deadweight, mt & 32729 & 35000 & 42648 & 38595 \\
\hline Draught, m & 8.10 & 7.60 & 11.10 & 8.80 \\
\hline Net capacity, mt & 26569 & 29151 & 35912 & 31713 \\
\hline Cargo capacity, m & 42857 & 44183 & 51912 & 50879 \\
\hline GRT & 19891 & 22115 & 24987 & 23703 \\
\hline NRT & 11021 & 12814 & 18975 & 13524 \\
\hline Holds/Hatches & $5 / 5$ & $5 / 5$ & $5 / 5$ & $5 / 5$ \\
\hline LOA, m & 177.00 & 180.00 & 181.50 & 179.99 \\
\hline Beam, m & 28.40 & 30.00 & 30.50 & 30.00 \\
\hline Depth, m & 14.20 & 15.80 & 16.10 & 16.60 \\
\hline Service speed full-loaded, knots & 14.5 & 14.0 & 12.0 & 13.8 \\
\hline Service speed in ballast, knots & 15 & 14.3 & 12.5 & 14.2 \\
\hline Purchase price of the vessel, thousand USD & 8000 & 7250 & 5510 & 13900 \\
\hline $\begin{array}{c}\text { Sale price of the vessel after using } \\
\text { for five years, thousand USD }\end{array}$ & 5300 & 5250 & 3500 & 10200 \\
\hline
\end{tabular}

Table 2

Changes in high viscosity fuel consumption depending on the speed of the expectant vessels

\begin{tabular}{|c|c|c|c|c|}
\hline \multirow{2}{*}{$\begin{array}{c}\text { Speed, } \\
\text { knots }\end{array}$} & \multicolumn{4}{|c|}{ Fuel consumption, ton/day } \\
\cline { 2 - 5 } & Vessel 1 & Vessel 2 & Vessel 3 & Vessel 4 \\
\hline 5.0 & 6.16 & 6.47 & 9.53 & 4.36 \\
\hline 5.5 & 6.48 & 6.89 & 10.07 & 4.74 \\
\hline 6.0 & 6.86 & 7.36 & 10.70 & 5.18 \\
\hline 6.5 & 7.28 & 7.91 & 11.42 & 5.68 \\
\hline 7.0 & 7.77 & 8.53 & 12.23 & 6.25 \\
\hline 7.5 & 8.31 & 9.22 & 13.14 & 6.89 \\
\hline 8.0 & 8.92 & 9.99 & 14.15 & 7.60 \\
\hline 8.5 & 9.59 & 10.85 & 15.27 & 8.39 \\
\hline 9.0 & 10.32 & 11.78 & 16.50 & 9.25 \\
\hline 9.5 & 11.13 & 12.81 & 17.84 & 10.20 \\
\hline 10.0 & 12.00 & 13.92 & 19.30 & 11.22 \\
\hline 10.5 & 12.95 & 15.13 & 20.89 & 12.34 \\
\hline 11.0 & 13.97 & 16.43 & 22.59 & 13.54 \\
\hline 11.5 & 15.07 & 17.83 & 24.43 & 14.83 \\
\hline 12.0 & 16.25 & 19.33 & 26.40 & 16.21 \\
\hline 12.5 & 17.51 & 20.94 & - & 17.69 \\
\hline 13.0 & 18.85 & 22.65 & - & 19.27 \\
\hline 13.5 & 20.28 & 24.48 & - & 20.95 \\
\hline 13.8 & 21.18 & 25.62 & - & 22.00 \\
\hline 14.0 & 21.80 & 26.40 & - & - \\
\hline 14.5 & 23.40 & - & - & - \\
\hline
\end{tabular}

For further study, we will consider several alternative options for acquiring bulk carriers for the transport of grain cargoes from Ukrainian ports to the ports of China and other countries in Southeast Asia. The main characteristics of the considered expectant vessels are given in Table 1.
In Fig. 1 the graphs of changes in consumption of fuel IFO 380, depending on the speed of the considered vessels are shown.

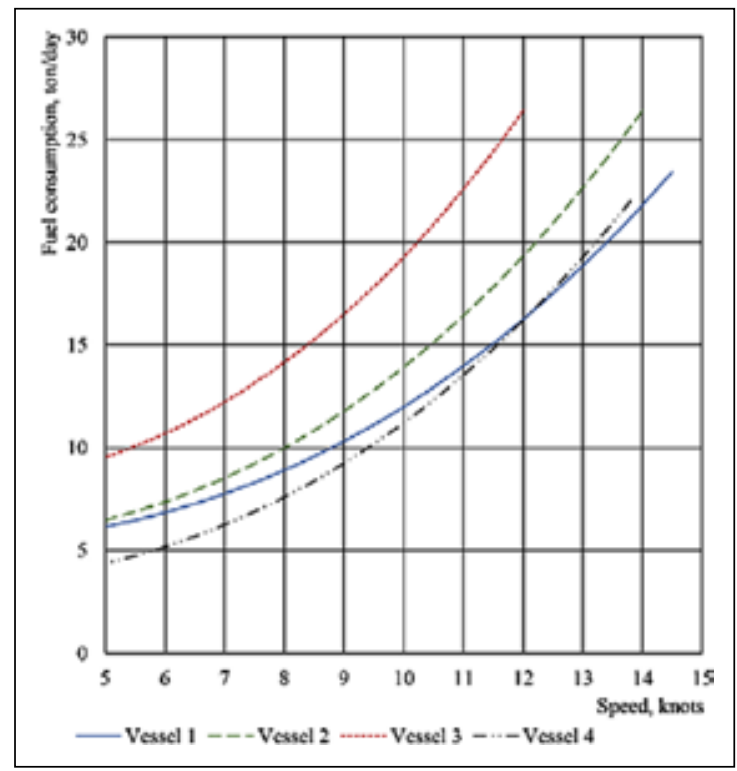

Fig. 1. Comparison of high viscosity fuel consumption dependencies on the speed for the considered expectant vessels

Changes in consumption of fuel IFO 380, depending on the speed of the expectant vessels, are presented in Table. 2.

Evaluation of time-charter equivalent values depending on the vessel speed. In order to evaluate the efficiency of the use of the expectant vessels, the operational performance indicators of these vessels in several routes were calculated. The value of 
freight, fixed and variable costs (including the cost of combustibles and lubricants) and time of voyage for each vessel and each direction depending on the selected speed of the vessels were found. Based on these indicators, the TCE (Time Charter Equivalent) values over all directions were calculated for each of the vessels considered, depending on the speed of the vessels. The changes in the TCE values depending on the speed of the expectant vessels are presented in Table 3.

Table 3

\section{The changes in the TCE values depending} on the speed of the considered vessels

\begin{tabular}{|c|c|c|c|c|}
\hline \multirow{2}{*}{$\begin{array}{c}\text { Speed, } \\
\text { knots }\end{array}$} & \multicolumn{4}{|c|}{ TCE, USD/day } \\
\cline { 2 - 5 } & Vessel 1 & Vessel 2 & Vessel 3 & Vessel 4 \\
\hline 5.0 & 6.16 & 6.47 & 9.53 & 4.36 \\
\hline 5.5 & 6.48 & 6.89 & 10.07 & 4.74 \\
\hline 6.0 & 6.86 & 7.36 & 10.70 & 5.18 \\
\hline 6.5 & 7.28 & 7.91 & 11.42 & 5.68 \\
\hline 7.0 & 7.77 & 8.53 & 12.23 & 6.25 \\
\hline 7.5 & 8.31 & 9.22 & 13.14 & 6.89 \\
\hline 8.0 & 8.92 & 9.99 & 14.15 & 7.60 \\
\hline 8.5 & 9.59 & 10.85 & 15.27 & 8.39 \\
\hline 9.0 & 10.32 & 11.78 & 16.50 & 9.25 \\
\hline 9.5 & 11.13 & 12.81 & 17.84 & 10.20 \\
\hline 10.0 & 12.00 & 13.92 & 19.30 & 11.22 \\
\hline 10.5 & 12.95 & 15.13 & 20.89 & 12.34 \\
\hline 11.0 & 13.97 & 16.43 & 22.59 & 13.54 \\
\hline 11.5 & 15.07 & 17.83 & 24.43 & 14.83 \\
\hline 12.0 & 16.25 & 19.33 & 26.40 & 16.21 \\
\hline 12.5 & 17.51 & 20.94 & - & 17.69 \\
\hline 13.0 & 18.85 & 22.65 & - & 19.27 \\
\hline 13.5 & 20.28 & 24.48 & - & 20.95 \\
\hline 13.8 & 21.18 & 25.62 & - & 22.00 \\
\hline 14.0 & 21.80 & 26.40 & - & - \\
\hline 14.5 & 23.40 & - & - & - \\
\hline
\end{tabular}

In Fig. 2 the curves of the changes in the average values of the TCE, depending on the speed of the expectant vessels, are shown.

Impact evaluation of the vessel speed on the performance values. The analysis of the efficiency of long-term investments, which include the acquisition of vessels, is quite complicated. It is associated with long time intervals and requires a comprehensive assessment of future conditions.

In assessing the efficiency of the acquisition and operation options of the considered expectant vessels, we will take as a basis the standard methods for evaluating projects in maritime transport described in $[20]$.

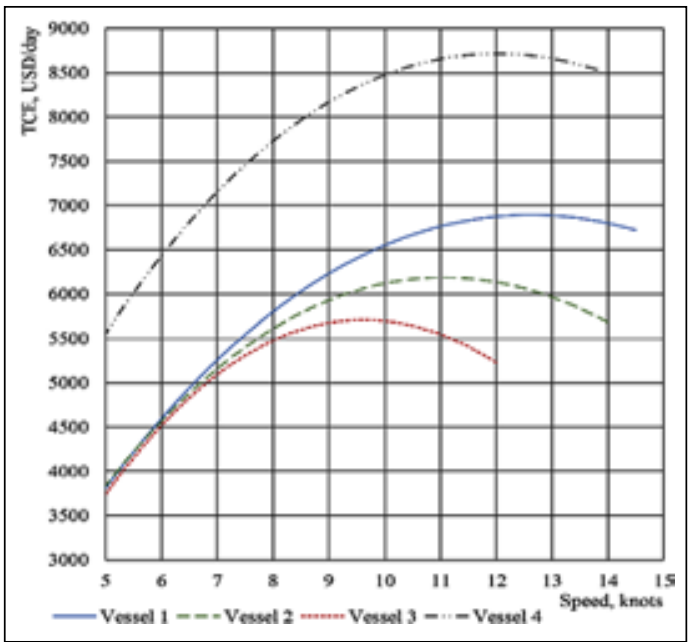

Fig. 2. The changes in the average values of the TCE depending on the speed of the expectant vessels

To calculate the NPV values of the projects considered for the acquisition and operation of vessels, it is necessary to estimate all the cash flows associated with these projects. The cash flow $C F_{i}$ for year $i$ is the difference between incomes and costs incurred in operating the vessel, including credit costs. It is calculated by the formula

$$
C F_{i}=T C E \cdot T_{e}-R_{i}^{\text {perm }}-R_{i}^{\text {fixed }},
$$

where TCE - the weighted average time charter equivalentforalldirections oftransportation, USD/day; $R_{i}^{\text {fxxed }}$ - the fixed costs during the vessel operation for year $i, \mathrm{USD} ; R_{i}^{\text {cred }}$ - the credit costs for year $i$, USD; $T_{e}$ - the period of the vessel operation during the year, days.

The fixed costs during the vessel operation include the crew's salary, expenses related to maintaining the vessel in proper technical condition, as well as insurance fees.

The value of the central indicator of the efficiency of the acquisition and operation option of the vessel (NPV, Net Present Value) is determined by the formula

$$
N P V=\sum_{i=1}^{T} \frac{C F_{i}}{\left(1+\frac{p}{100}\right)^{i}}+\frac{I_{\text {sale }}}{\left(1+\frac{p}{100}\right)^{T}}-I_{0}^{\text {own }} \text {, }
$$

where $T$ - the time period considered, years; $p$ - the discount rate, $\% ; I_{0}^{o w n}$ - the volume of investment at the expense of own funds, USD; $I_{\text {sale }}-$ the estimated cost of selling the vessel after its operation during $T$ years, USD.

In Table 4 the calculations of the NPV values for the considered acquisition and operation options of the vessels under the condition of movement of vessels at different speeds are shown. 
Table 4

Changes in the NPV values for the acquisition and operation options of the vessels depending on the speed

\begin{tabular}{|c|c|c|c|c|}
\hline \multirow{2}{*}{$\begin{array}{c}\text { Speed, } \\
\text { knots }\end{array}$} & \multicolumn{4}{|c|}{ NPV, thousand USD } \\
\hline 5essel 1 & Vessel 2 & Vessel 3 & Vessel 4 \\
\hline $\mathbf{5 . 0}$ & $\mathbf{- 2 4 2 2 . 6 1}$ & $\mathbf{- 1 4 0 1 . 1 4}$ & $\mathbf{- 9 0 7 . 6 3}$ & $\mathbf{- 3 2 8 8 . 1 7}$ \\
\hline 5.5 & -1914.87 & -924.16 & -392.28 & -2720.66 \\
\hline 6.0 & -1446.48 & -492.38 & 58.71 & -2202.00 \\
\hline 6.5 & -1016.30 & -104.89 & 446.90 & -1730.86 \\
\hline 7.0 & -623.72 & 239.05 & 773.74 & -1306.07 \\
\hline 7.5 & -267.99 & 540.28 & 1040.60 & -926.37 \\
\hline 8.0 & 51.60 & 799.57 & 1248.82 & -590.62 \\
\hline 8.5 & 335.74 & 1017.67 & 1399.68 & -297.73 \\
\hline 9.0 & 585.08 & 1195.30 & 1494.35 & -46.67 \\
\hline 9.5 & 800.26 & 1333.16 & 1534.00 & 163.54 \\
\hline 10.0 & 981.87 & 1431.94 & 1519.82 & 333.84 \\
\hline 10.5 & 1130.52 & 1492.26 & 1452.38 & 465.10 \\
\hline 11.0 & 1246.75 & 1514.74 & 1334.20 & 558.18 \\
\hline 11.5 & 1331.10 & 1500.07 & 1162.49 & 613.93 \\
\hline 12.0 & 1384.17 & 1448.55 & 943.57 & 632.75 \\
\hline 12.5 & 1406.15 & 1360.95 & - & 616.24 \\
\hline 13.0 & 1397.93 & 1238.88 & - & 564.56 \\
\hline 13.5 & 1360.62 & 1077.96 & - & 474.22 \\
\hline 13.8 & 1322.57 & 965.18 & - & 408.98 \\
\hline 14.0 & 1290.32 & 887.07 & - & - \\
\hline 14.5 & 1195.42 & - & - & - \\
\hline \multicolumn{5}{|c}{} \\
\hline
\end{tabular}

In Fig. 3 the curves of changes in the efficiency indicator values (2) depending on the speed of the expectant vessels are shown.

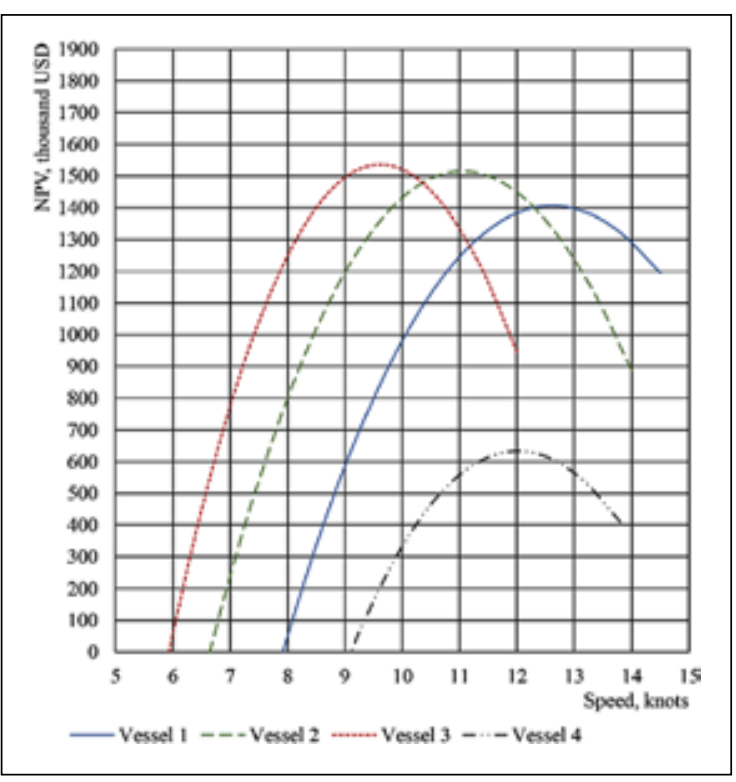

Fig. 3. Dependence of the NPV values for the acquisition and operation options of the expectant vessels on the speed

Fig. 3 shows that when vessels are moving at maximum speeds, the NPV values will not be the greatest. In Table 5 the NPV values for the acquisition and operation options of the expectant vessels are presented when the vessels are moving at service (maximum) speeds.

Table 5

The NPV values for the acquisition and operation options of the expectant vessels when moving at service speeds

\begin{tabular}{|c|c|c|}
\hline Vessels & $\begin{array}{c}\text { Vessel service } \\
\text { speed, knots }\end{array}$ & $\begin{array}{c}\text { NPV value, } \\
\text { thousand USD }\end{array}$ \\
\hline Vessel 1 & 14.50 & 1195.42 \\
\hline Vessel 2 & 14.00 & 887.07 \\
\hline Vessel 3 & 12.00 & 943.57 \\
\hline Vessel 4 & 13.80 & 408.98 \\
\hline
\end{tabular}

A gradual decrease in the vessel speed to a certain level leads to a reduction in fuel consumption and, consequently, a decrease in the NPV values. For each expectant vessel there is an optimal speed at which the NPV reaches its maximum value. These values are given in Table 6. However, a further decrease in speed, being below the values presented in Table 5, is impractical, as both a decrease in the NPV values and an increase in the voyage time will be observed.

Table 6

The maximum NPV values that can be achieved while reducing the speed of the expectant vessels

\begin{tabular}{|c|c|c|}
\hline Vessels & $\begin{array}{c}\text { Optimal speed, } \\
\text { knots }\end{array}$ & $\begin{array}{c}\text { Maximal NPV value, } \\
\text { thousand USD }\end{array}$ \\
\hline Vessel 1 & 12.32 & 1401.98 \\
\hline Vessel 2 & 11.20 & 1513.29 \\
\hline Vessel 3 & 9.60 & 1545.44 \\
\hline Vessel 4 & 11.73 & 627.14 \\
\hline
\end{tabular}

The data presented in Fig. 3, Table 4 and Table 6 allow us to make a substantiated choice of the vessel, taking into account the possibility of its operation at various speeds. So, from Fig. 3 it can be seen that Vessel 4 is inferior at any speed to the other vessels considered, therefore its acquisition is inexpedient.

In order to minimize the average voyage duration, Vessel 1 should be chosen and used at maximum speeds. In this case, the speed will be 14.5 knots, that will minimize the voyage time. However, in this case, the value of NPV for Vessel 1 will be only 1.2 thousand USD.

Choosing Vessel 3 and using it at a speed of 9.6 knots can achieve the maximum NPV. In this case, the NPV value will increase to 1.54 thousand USD, which is 0.6 thousand USD more than the NPV value for the same vessel, provided it is used at a maximum speed of 12 knots. 
It is obvious that the use of any of the considered expectant vessels at a speed lower than 9.6 knots provides a lower value of the efficiency indicator, which is disadvantageous both for the ship owner and for the cargo owner.

Fig. 3 shows that Vessel 2 presents the best NPV values when used in the speed range from 10.3 to 12.3 knots. The maximum NPV for Vessel 2 is slightly lower than the maximum NPV for Vessel 3. But at the same time, Vessel 2 has better speed characteristics than Vessel 3.

Conclusions. The vessel operation at slow speeds helps to achieve a significant reduction in fuel con- sumption and, consequently, effectively serves for operating costs reduction. The studies have shown that the efficiency of the acquisition and operation options of bulk carriers can be significantly improved through a reasonable choice of the vessel speed. From the calculations it is clear that the choice of a vessel depends on the speed regimes that these vessels are planned to operate. At different speed regimes, the best values of performance indicators can be achieved using different vessels. The proposed method allows the decision maker to make a substantiated choice of the option for acquiring the vessel, taking into an account the possibility of operating it at different speeds.

\section{References:}

1. Revenko V.L., Lapkina I.A. Methods and models of investment analysis in the shipping industry. Cybernetics and Systems Analysis. 1997. № 4 (33). PP. 571-580. DOI: https://doi.org/10.1007/BF02733114

2. Rakhovetskiy A.N. Operational freight activity in the maritime transport, Moscow : Transport, 1986. $160 \mathrm{p}$.

3. Kapitonov I.V. Efficiency reserves of ships operations, Moscow Transport, 1990. 221 p.

4. Bulut E., Duru O., Yoshida S. Market entry, asset returns, and irrational exuberance: Asset management anomalies in dry cargo shipping. International Journal of Shipping and Transport Logistics. 2013. № 5 (6). PP. 652-667. DOI: http://dx.doi.org/10.1504/IJSTL.2013.056851

5. Özdemir Ü., Güneroğlu A. Cargo type selection procedure using fuzzy AHP and fuzzy TOPSIS techniques: The case of dry bulk cargo ships. International Journal of Shipping and Transport Logistics. 2018. № 10 (3). PP. 259-280. DOI: https://doi.org/10.1504/IJSTL.2018.091673

6. Notteboom T., Cariou P. Slow steaming in container liner shipping: is there any impact on fuel surcharge practices? The International Journal of Logistics Management, 2013. № 24 (1). PP. 73-86. DOI: https://doi.org/10.1108/IJLM-05-2013-0055

7. Lapkina I., Malaksiano M. Estimation of fluctuations in the performance indicators of equipment that operates under conditions of unstable loading. Eastern-European Journal of Enterprise Technologies. 2018. № 1 (3 (91)). PP. 22-29. DOI: https://doi.org/10.15587/1729-4061.2018.123367

8. Lapkina I.O., Malaksiano M.O. (2016). Modelling and optimization of perishable cargo delivery system through Odesa port. Actual Problems of Economics. 2016. № 3(177). PP. 353-365.

9. Kraev V.I., Stupin, O.K., Limonov E.L. (1973). Economic justification for the design of marine cargo ships, L. Shipbuilding. $294 \mathrm{p}$.

10. Lapkina I.O., Malaksiano M.O., Malaksiano M.O. (2016). Optimization of the structure of sea port equipment fleet under unbalanced load. Actual Problems of Economics. 2016. № 9 (183). PP. 364-371.

11. Malaksiano N.A. On the stability of economic indicators of complex port equipment usage. Actual Problems of Economics. 2012. № 12 (138). PP. 226-233.

12. Lapkina I., Malaksiano M. Elaboration of the equipment replacement terms taking into account wear and tear and obsolescence. Eastern-European Journal of Enterprise Technologies. 2018. № 3 (3 (93)). PP. 30-39. DOI: https://doi.org/10.15587/1729-4061.2018.133690

13. Sharifi Y., Ghassemi H., Zanganeh H. (). Various Innovative Technologic Devices in Shipping Energy Saving and Diminish Fuel Consumption. International Journal of Physics. 2017. № 5 (1). PP. 21-29. DOI: 10.12691/ijp-5-1-4

14. Veenstra A.W., Van Dalen J. Ship Speed and Fuel Consumption Quotation in Ocean Shipping Time Charter Contracts. Journal of Transport Economics and Policy. 2011. № 45 (1). PP. 41-61.

15. Ronen D. The effect of oil price on containership speed and fleet size. Journal of the Operational Research Society. 2011. № 62(1). PP. 211-216. DOI: https://doi.org/10.1057/jors.2009.169

16. Wang S., Meng Q., Liu Z. Bunker consumption optimization methods in shipping: A critical review and extensions. Transportation Research Part E: Logistics and Transportation Review. 2013. № 53. PP. 49-62. DOI: https://doi.org/10.1016/j.tre.2013.02.003

17. Lapkina I.A., Akimova O.V. Determination of the optimal operational speed of container ships when the volume of traffic on the line changes. Methods and tools for managing the development of transport systems. 2011. № 18. PP. 165-181. 
18. Jae-Gon Kim, Hwa-Joong Kim, Paul Tae-Woo Lee. Optimizing ship speed to minimize fuel consumption. Transportation Letters. 2014. № 6(3). PP. 109-117. DOI: https://doi.org/10.1179/1942787514Y.0000000016

19. Lapkina I.O., Malaksiano M.O., Glavatskykh V.I. A multi-criteria approach to justifying the choice of a project of bulk carrier vessel acquiring and operating. Collection of scientific works of DUIT. Series "Transport Systems and Technologies”. 2019. № 33(2). PP. 99-111.

20. Lapkina I.A., Pavlovskaya L.A., Boldyreva T.V., Shutenko T.N. Project analysis: theoretical foundations for evaluating projects in maritime transport. Odessa : Feniks, 2008. 315 p.

\section{Лапкіна І.О., Малаксіано М.О., Главатських В.І. ЩОДО ПИТАННЯ ПРО МОЖЛИВІСТЬ ЕКСПЛУАТАЦІЇ СУДЕН НА УПОВІЛЬНЕНИХ ШВИДКОСТЯХ}

Нестабільність фрахтового ринку зумовлює високий рівень конкурениії між судноплавними компаніями. Для того, щоб підвищити свою конкурентоспроможність на фрахтовому ринку, власники суден і оператори флоту змушені оптимізувати свої витрати, в тому числі витрати на споживання палива. Оскільки витрати палива безпосередньо залежсать від швидкості руху судна, експлуатація суден на уповільнених швидкостях широко використовується у світовій практиці. Тому дослідження, що спрямовані на вибір економічно обтрунтованої швидкості руху суден, особливо актуальні.

У роботі досліджено иляхи підвищення ефективності операційної фази проектів поповнення флоту з урахуванням можливості експлуатації суден на уповільнених швидкостях. Для иього проведено аналіз залежності витрат палива від швидкості руху суден. Аналіз ефективності довгострокових інвестицій, які включають у себе придбання та експлуатацію суден, представляє значні труднощі. Це пов'язано з необхідністю розгляду тривалих горизонтів планування і вимагає комплексної оцінки майбутніх умов експлуатаиії суден. У роботі були вивчені зміни експлуатаційних показників роботи суден і зміни значень чистої сучасної вартості (NPV) для різних проектів поповнення флоту судноплавних компаній залежно від вибору швидкісних режимів руху суден. Було показано, як ефективність експлуатаиії суден-балкерів може бути значно підвищена завдяки обтрунтованому вибору швидкості руху суден.

Розрахунки показали, що при різних швидкісних режимах найкращі значення показників ефективності можуть бути досягнуті иляхом використання різних суден. Тому оптимальний вибір судна істотно залежсить від того, на яких швидкісних режимах планується його експлуатувати. Виконане дослідження дає змогу робити обтрунтований вибір варіанту придбання $і$ подальшої експлуатації судна-балкера.

Ключові слова: перевезення навалочних вантажів, витрати палива, оптимальна швидкість, морський транспорт, знижена швидкість. 